\title{
Distance Education And Women Empowerment: The Women Who Dared At Distance Learning Institute
}

A.O. Okunuga, University Of Lagos, Nigeria

M. O. Akintayo, University of Ibadan, Nigeria

\begin{abstract}
In the past, the African female child had always been denied formal education due to various cultural and social prejudices. Distance education has been employed by numerous women, who had earlier thus been deprived, to bridge the educational gap between males and females in the country.

These are mature females, of which the majority (54\%) are within the age range of 30-39 years. Most are employed, married (89\%) and with children (89\%). The majority (60\%) study between 10 and 15 hours per week. Their reasons for studying through Distance Education vary and include attainment of higher education (80\%), improved knowledge (86\%), enhanced employment opportunities (47\%), upgrading/promotion at work (90\%), and improved economic power (21\%) and social status (81\%); a few (10\%) have their sights set on the political terrain.
\end{abstract}

Keywords: distance learning; open and distance learning; women empowerment; face-to-face teaching; residential period

\section{INTRODUCTION}

\section{Historical Background Of Education In Nigeria}

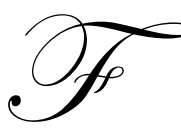

ormal education in Nigeria dates back to 1842 when Ferguson succeeded in persuading local Yoruba chiefs to allow missionaries from Sierra Leone to teach their sons. Between 1842 and 1843, three missionaries of the Church Missionary Society (CMS) arrived on the Nigerian soil. Two years later (1845), Bishop Samuel Ajayi Crowther and his wife built two separate schools-one for boys, one for girls. With this development, other missionaries started arriving in Nigeria with the Reverend Hope Waddel in 1846. In 1853, the first non-British Christian Missionary entered Nigeria to also establish missionary schools (Aderinoye, 2006).

However, most of the schools were mainly for boys, while the few girls' schools were limited to teaching the girl-child up to the elementary school, with emphasis on vocational/domestic science. Besides this, most parents preferred to send their male offsprings to school at the expense and negligence of the girl-child. The thinking was that the male-child propagates the family name, while the female-child ceases to be recognized with the family name after her marriage (Ativie, 1997).

Other social and cultural prejudices include the beliefs that:

- $\quad$ women's place is in the kitchen;

- $\quad$ they are of low intelligence compared to men; and for this reason, any investment on them is a waste;

- $\quad$ they cannot bring fame and honour to their father's name once they marry; only the male child who carries forth the family name can bring such fame;

- $\quad$ they cannot support their parents financially after marriage;

- $\quad$ their education may be hampered by early pregnancy due to pre-marital sex relationship. 
The result of these prejudices was that girls were denied access to basic education in preference to boys (Bamisaye, 2008). In some parts of the country like in the Eastern states, girls are given out in early marriage; and especially in Northern Nigeria, because of religious beliefs, girls are not allowed access to education (Yinusa, 1999). This is so because of the small number of female teachers, and parents are not happy to have their female children taught by male teachers. Today, in the northern part of Nigeria, girls are begged and paid to go to school, while various legislations are enacted to discourage parents from withdrawing their female children from school for early marriages (Bamisaye, 2008).

Those women from Eastern Nigeria who were denied access to education as a result of early marriages, and those from the West who could not obtain tertiary education for financial constrains, are now mostly beneficiaries of distance education. This positive development stems from the positive attitude of the government, e.g. through the Family Economic Advancement Programme (FEAP) and non-governmental organisations' efforts, e.g. Women in Policy (WIP), towards educating women (Yinusa, 1999).

The enrolment in distance education has helped women to a greater extent in achieving against so many odds, educational, social and political prominence (Obiona, 1993; Obodeh, 1997). It has also led to new skills, training, enhanced employment opportunities, improved working conditions, outspokenness on public affairs, increased involvement in politics, etc. Improved working conditions and improved promotional chances have in turn increased women's earning power and work options; hence distance education has granted economic independence and empowerment to women.

Empowerment simply means to enhance or give someone more control over his or her own life or situation. Power is not necessarily a function of status, gender, strength, size, intelligence or maturity. Rather, power is the ability to control few resources available to a family, communities or even a nation by whatever means. Power in a family or social relationship, for example, is based upon the answer to the following questions:

- Who does what?

- Who decides who does what? And

- Who decides the rules for determining (a) and (b)?

Power rests in the hands of the person in a system who individually or in concert with others controls the resources available to the members of the system (Yinusa, 1999).

This study was limited only to women studying for a university degree though the Distance Learning Institute (DLI) of the University of Lagos. This is because DLI is more broad-based than the other Sandwich, correspondence or distance learning institutions in Nigeria, which are somewhat regional or subregional (localized) in structure and outreach.

This study explored the profile of DLI female students, their reasons for studying through distance learning, their goals and aspirations and the benefits they have derived or hope to derive from their endeavours.

\section{METHODOLOGY}

Well-designed questionnaires were administered randomly to a total number of four hundred (400) DLI students. Two hundred questionnaires were distributed among female Business Administration and Accounting students while the remaining two hundred (200) were distributed among Science-Education female students in Biology, Chemistry, Physics and Mathematics cohorts.

The respondents were questioned on individual socio-economic and demographic characteristics and the effect of their studies on the family and social lives. It was prepared in a form that they gave full information about their life profiles, husbands, children and family parameters for studying, previous education, social life as well as child-bearing before and during their studies. The number of hours they allot to their studies per week was inclusive. 
The population of female students of DLI is in eight (8) study centres distributed all over the country. The Lagos Study Centre has the highest number of both male and female students. The survey was done during the Residential programme of 6-week intensive lectures and examinations when all the students congregate at the University of Lagos.

Three hundred and fifty respondents filled the questionnaires as requested; twenty-seven questionnaires filled unsatisfactorily were discarded while twenty-three respondents did not return their forms.

The data collected from the questionnaires was analysed descriptively using tables, which show the frequencies and percentages of each response. The responses were counted and the percentages determined.

\section{RESULTS}

One hundred percent of the respondents are females. Questions relating to a particular problem are grouped together and analyzed descriptively.

Table 1: Distribution Of Respondents By Age

\begin{tabular}{|c|c|c|}
\hline Age of respondents & Frequency & Percentage \\
\hline $20-29$ & 21 & 6.0 \\
\hline $30-39$ & 189 & 54.0 \\
\hline $40-49$ & 125 & 35.7 \\
\hline $50-59$ & 15 & 4.3 \\
\hline Total & 350 & 100.0 \\
\hline
\end{tabular}

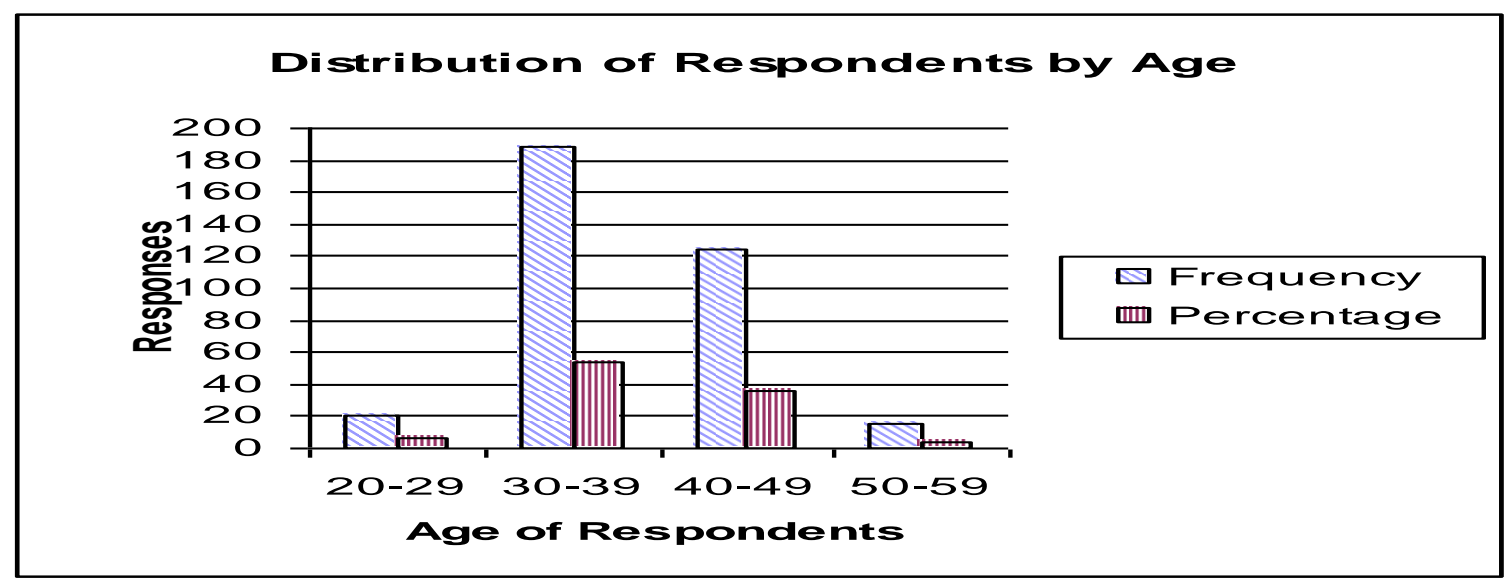

Table 1 shows that the majority of female students studying at a distance at DLI are between 30 and 39 years of age as $54 \%$ of the respondents fall into this age range. The next large age group is $40-49$ years. This shows that the DLI programmes of study are for mature students.

Table 2: Distribution Of Respondents By Occupation

\begin{tabular}{|c|c|c|}
\hline Occupation & Frequency & Percentage \\
\hline Teaching & 166 & 47.4 \\
\hline Civil Servants & 24 & 6.9 \\
\hline Private/company & 140 & 40.0 \\
\hline Housewives (full-time) & 9 & 2.6 \\
\hline Self-employed & 11 & 3.1 \\
\hline Total & 350 & 100.0 \\
\hline
\end{tabular}




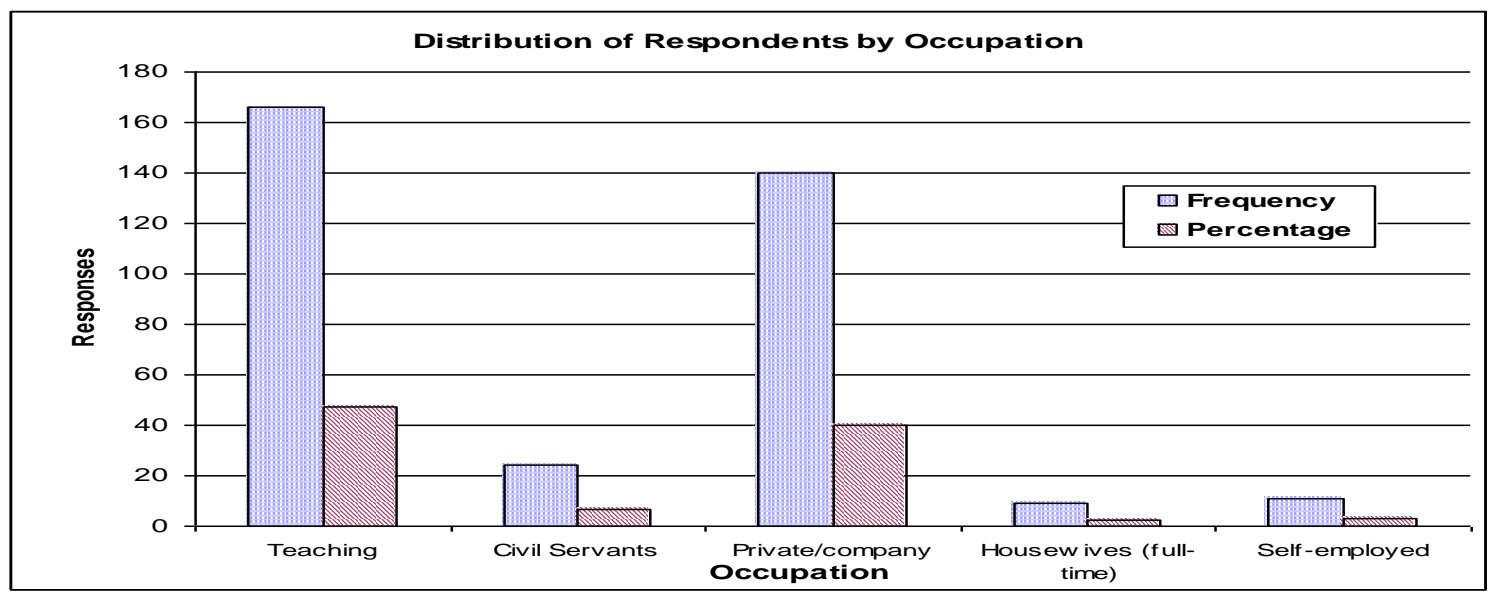

Table 2 shows that $47.4 \%$ of the respondents are teachers, $85 \%$ of whom are in the Science-Education Programme. Forty percent of the respondents work in the private/company sector, while $6.9 \%$ are civil servants. Two point six per cent $(2.6 \%)$ of them are full-time housewives. Nonetheless, all respondents combine housewife duties with their studies and employment.

Table 3: Marital Status Of Respondents

\begin{tabular}{|c|c|c|}
\hline Parameter & Frequency & \multicolumn{2}{c|}{ Percentage } \\
\hline Married & 313 & 9.4 \\
\hline Single & 32 & 0.1 \\
\hline Divorced & 2 & 0.6 \\
\hline Widowed & 3 & - \\
\hline Separated & - & 100.0 \\
\hline Total & 350 & \\
\hline
\end{tabular}

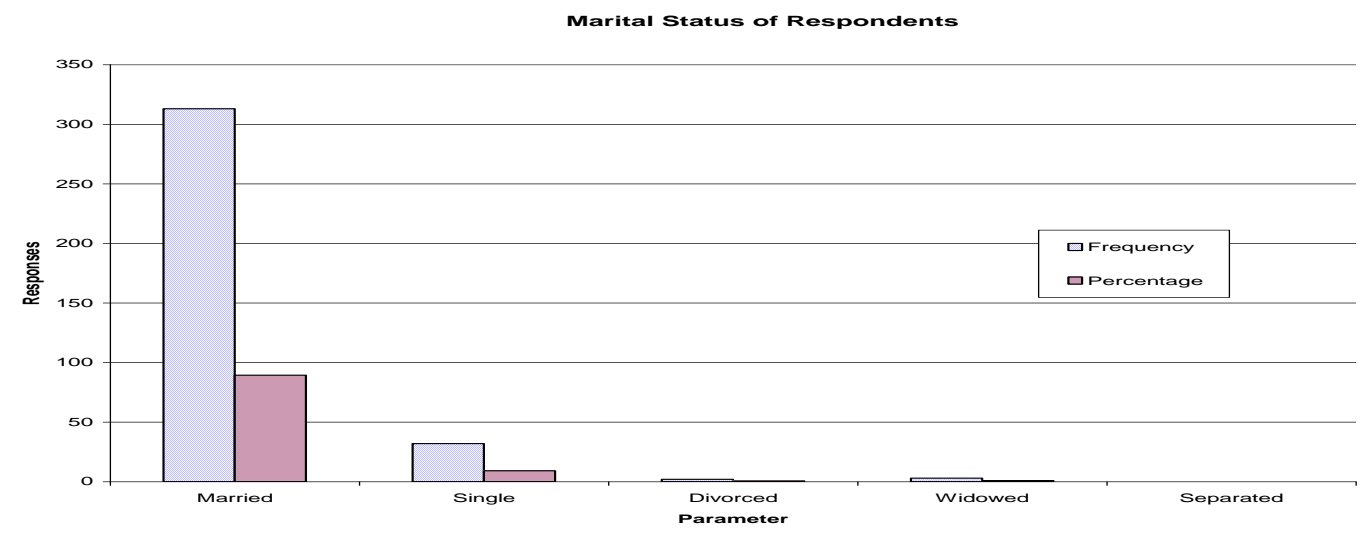

From Table 3, it is quite clear that the majority of the female students (89\%) are married. Thus they have family cares, work and other social duties competing with their time for studies. 
Table 4: Distribution Of Respondents By Length Of Marriage

\begin{tabular}{|c|c|c|}
\hline Length of Marriage & Frequency & Percentage \\
\hline $0-20$ years & 255 & 81.5 \\
\hline $20-25$ years & 47 & 15.0 \\
\hline $25-30$ years & 11 & 3.5 \\
\hline $30-35$ years & - & - \\
\hline Total & 313 & 100.0 \\
\hline
\end{tabular}

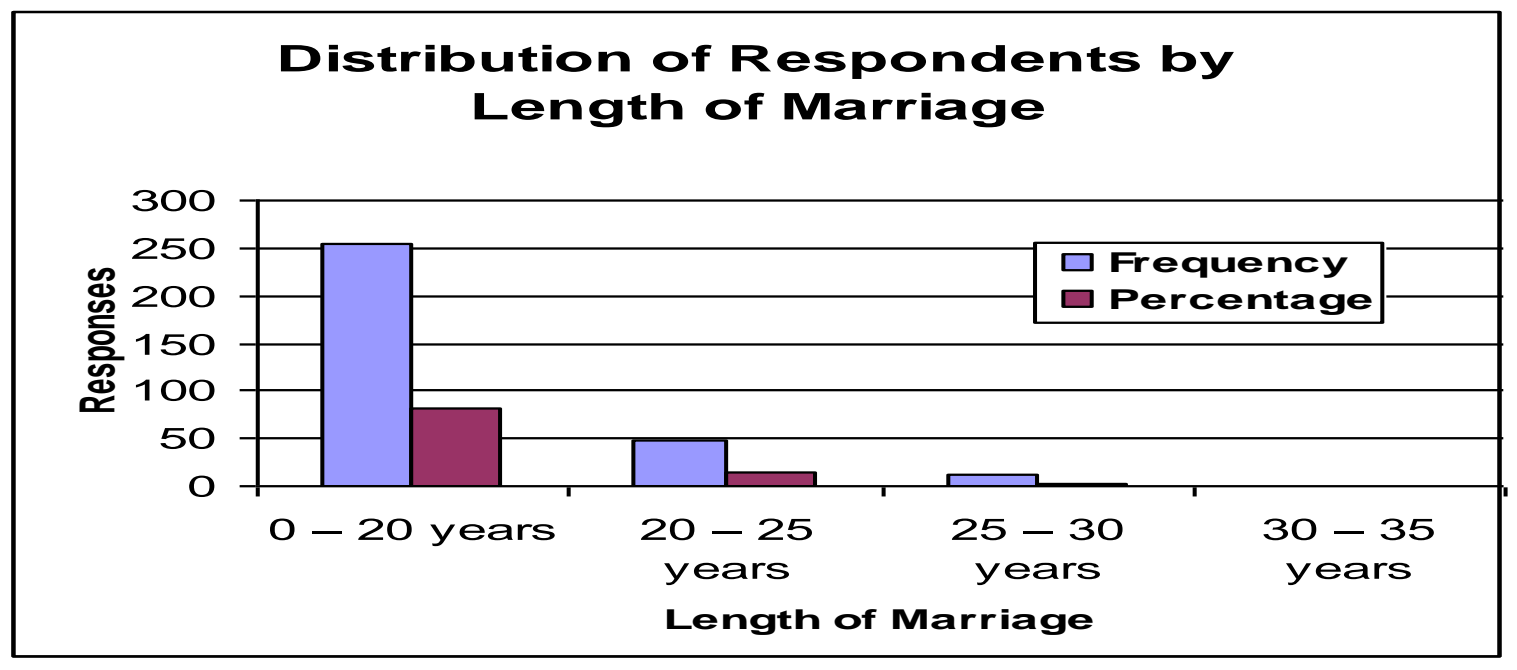

Table 4 shows that 81.5 percent of the respondents have been married for less than 20 years, while 15 percent have been married between 20 and 25 years. Only 3.5 percent of the respondents have been married for as long as $25-30$ years.

Table 5: Distribution Of Respondents By Marriage Before Starting With Distance Education

\begin{tabular}{|c|c|c|}
\hline Parameter & Frequency & Percentage \\
\hline Yes (married before DE) & 301 & 96.2 \\
\hline No (not married before DE) & 12 & 3.8 \\
\hline Total & 313 & 100.0 \\
\hline
\end{tabular}

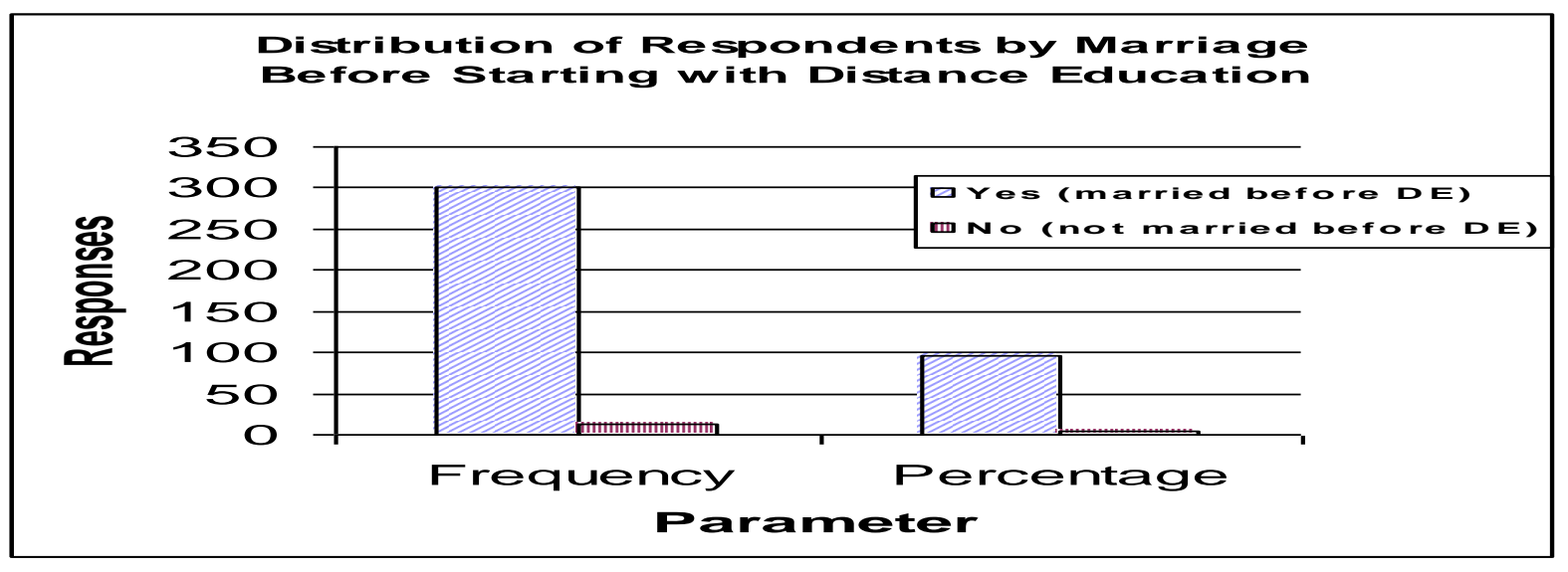


Table 5 reveals that 96.2 percent of the female students were already married before starting their DLI study programme. Three point eight percent were not married at the time of starting the distance education studies, but a few do get married along the line, even to DLI students.

Table 6: Number Of Children Borne By Respondents

\begin{tabular}{|c|c|c|}
\hline Number of Children & Frequency & Percentage \\
\hline 0 & 12 & 3.8 \\
\hline $1-2$ & 138 & 44.1 \\
\hline $3-4$ & 112 & 35.8 \\
\hline $5-6$ & 51 & 16.3 \\
\hline $7-8$ & - & - \\
\hline Total & 313 & 100.0 \\
\hline
\end{tabular}

\section{Number of Children Borne by Respondents}

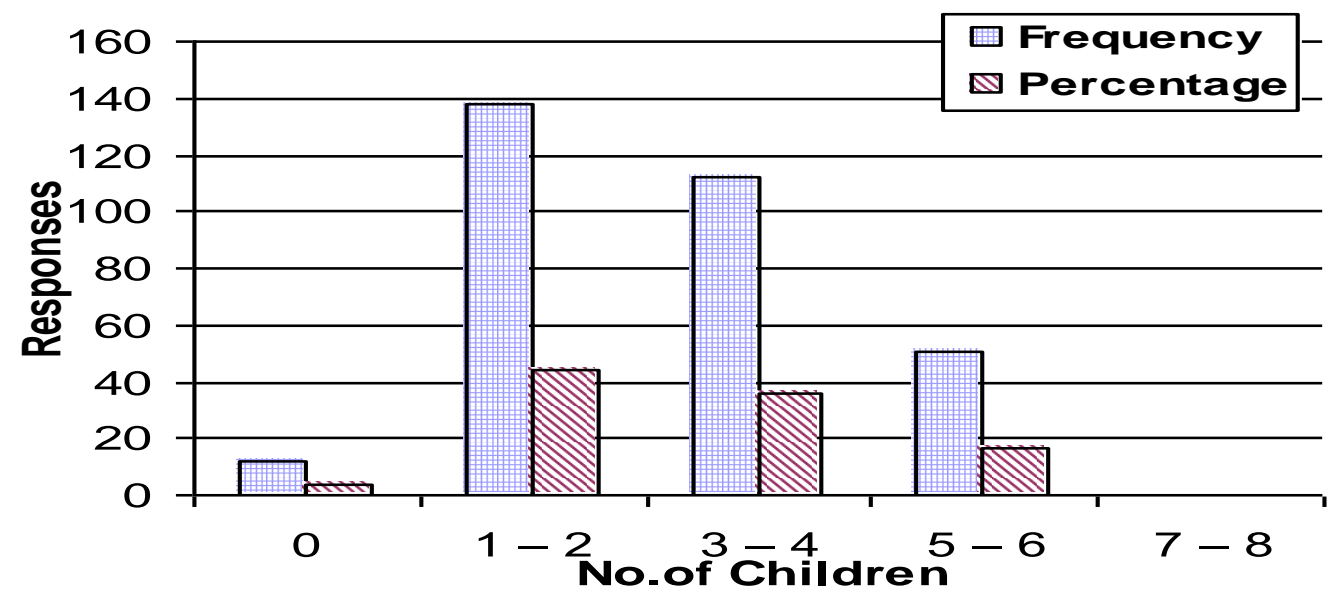

From Table 6, it can be seen that 44.1 percent of the respondents have one (1) or two (2) children, 35.8 percent have either three (3) or four (4); while 16.3 percent have 5 or 6 children. Only 3.8 per cent do not have any children; it is assumed that these are newly married or still earnestly praying for the fruit of the womb.

Table 7: Years Of Respondent's Working Experience

\begin{tabular}{|c|c|c|}
\hline Years of Working Experience & Frequency & Percentage \\
\hline $0-5$ & 23 & 6.7 \\
\hline $6-10$ & 101 & 29.3 \\
\hline $11-15$ & 93 & 27.0 \\
\hline $16-20$ & 91 & 26.4 \\
\hline $21-25$ & 32 & 9.2 \\
\hline 25 and above & 5 & 1.4 \\
\hline Total & 345 & 100.0 \\
\hline
\end{tabular}




\section{Years of Respondent's Working Experience}

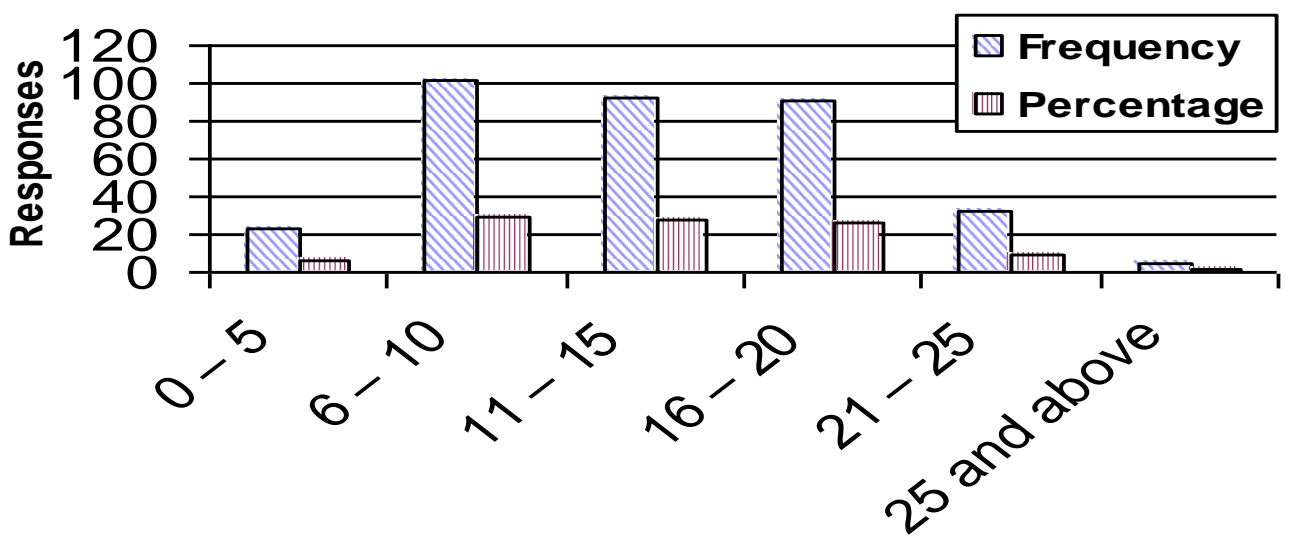

Years of Working Experience

Table 7 shows that $29.3 \%$ of the respondents have $6-10$ years of working experience, $27 \%$ have $11-15$ years working experience, while $26.4 \%$ have $16-20$ years of working experience, $6.7 \%$ have a maximum of five years working experience while $9.2 \%$ have worked for 21-25 years. Only $1.4 \%$ of the respondents have worked for more than 25 years.

Table 8: Study Time Per Week

\begin{tabular}{|c|c|c|}
\hline Study Hour & Frequency & Percentage \\
\hline Less than 10 & 100 & 28.6 \\
\hline $10-15$ & 213 & 80.8 \\
\hline $16-20$ & 31 & 1.9 \\
\hline $21-25$ & 5 & 0.3 \\
\hline $26-30$ & 1 & - \\
\hline More than 30 & - & 100.0 \\
\hline Total & 350 & \\
\hline
\end{tabular}

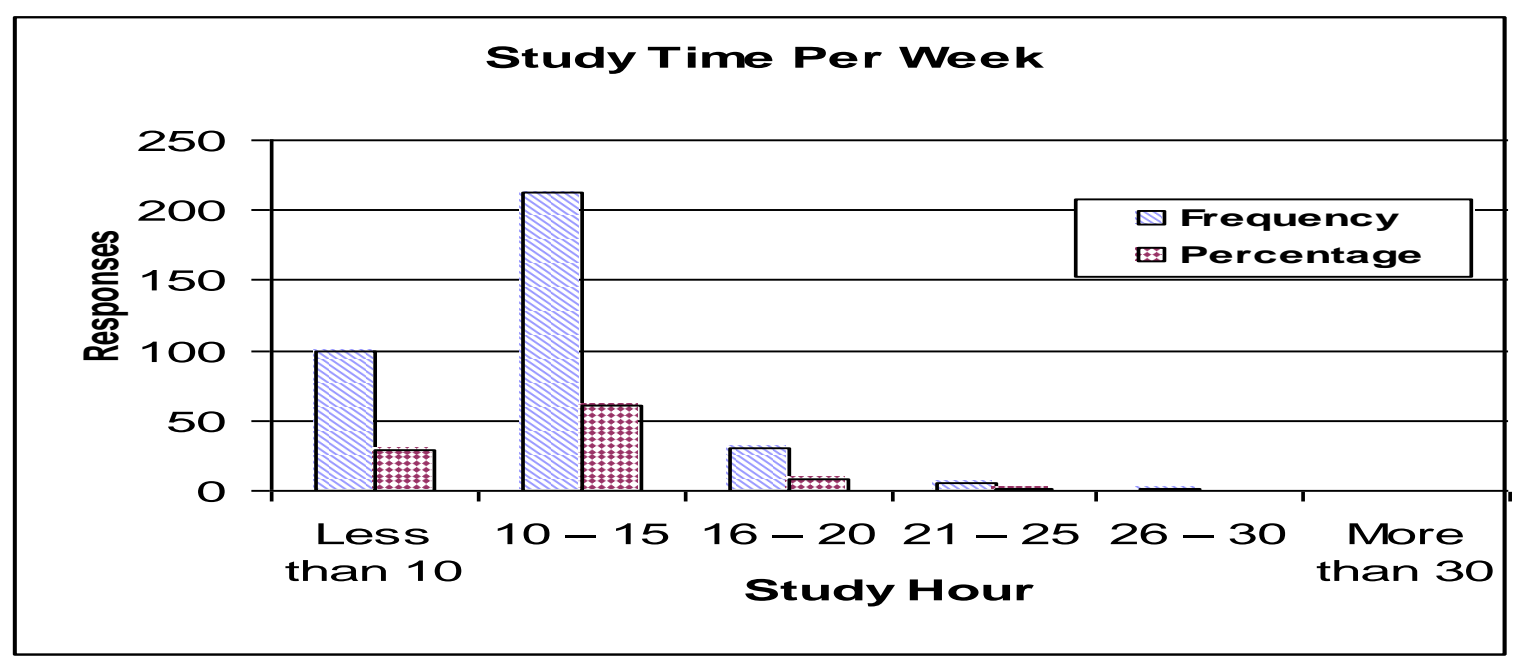


Table 8 shows the majority of the respondents (60.8\%) study between 10 and 15 hours per week; $28.6 \%$ study for less than ten hours per week, while only one student (i.e. $0.3 \%$ ) expends between 26 to 30 hours per week to study.

Table 9: Reasons For Studying Through Distance Education

\begin{tabular}{|c|c|c|}
\hline Parameter & Frequency & Percentage \\
\hline Higher educational attainment & 280 & 80.0 \\
\hline Economic power & 73 & 20.9 \\
\hline Politics & 36 & 10.3 \\
\hline Enhanced employment opportunity & 164 & 46.8 \\
\hline Improved upgrading/promotion & 315 & 90.0 \\
\hline Improved knowledge & 305 & 86.0 \\
\hline Status (social) & 283 & 80.9 \\
\hline
\end{tabular}

(Respondents were asked to choose as many options as applicable to them).

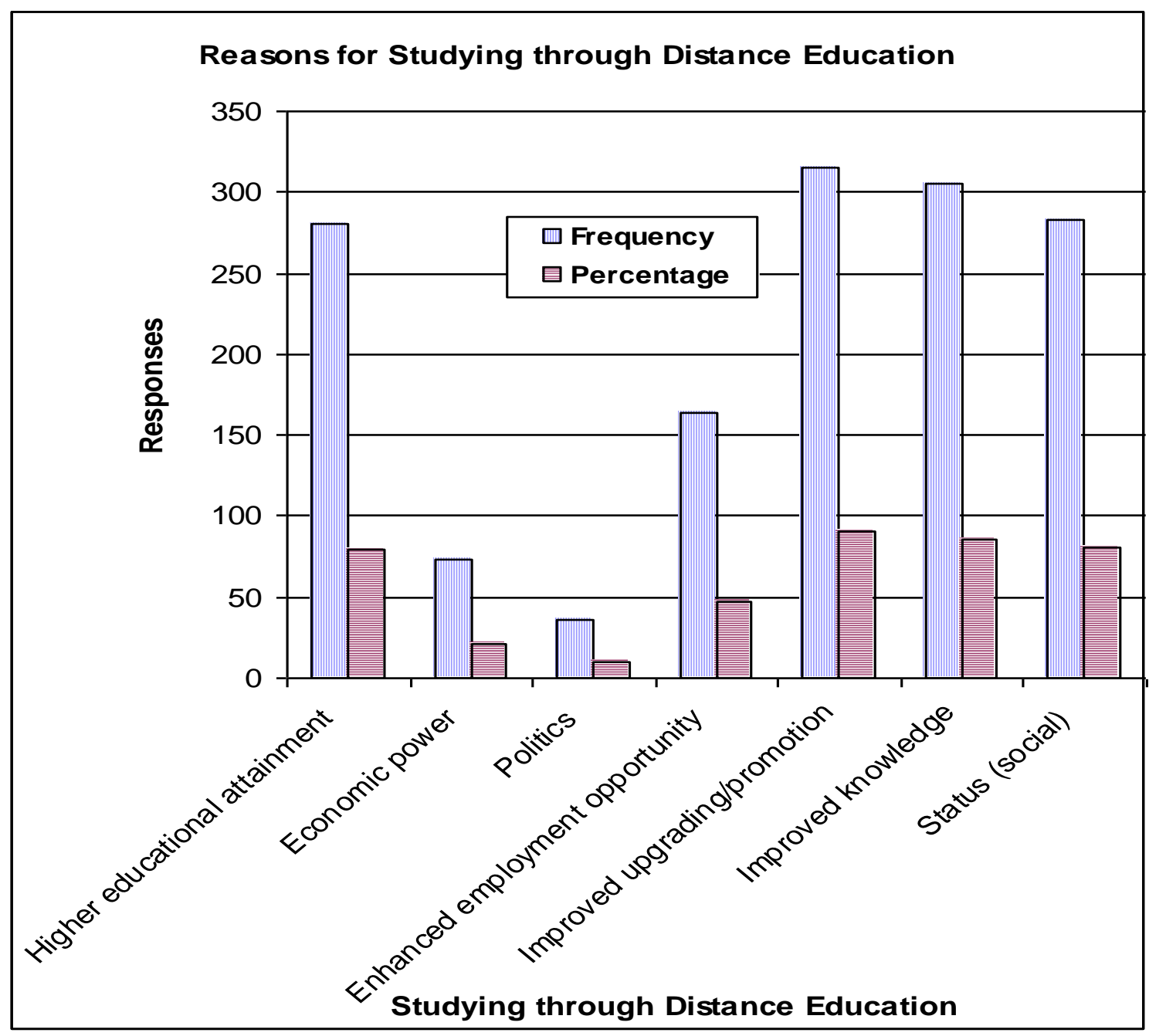

Table 9 shows enhancement of promotion at work induced $90 \%$ of the respondents to study for a degree through distance studies. Eighty six percent are driven by the thirst for knowledge. Attainment of higher 
educational $(80 \%)$ and social status $(80.9 \%)$ are also driving forces. Forty six point eight percent of the respondents would want to change jobs, while $10.3 \%$ are gearing for politics. Twenty point nine percent were influenced by the need for improved economic power.

Table 10: Distribution Of Respondents' Husbands By Educational Levels And Relevant Occupations

\begin{tabular}{|c|c|c|c|c|}
\hline Educational Level & Frequency & Percentage & Relevant Level/ Occupation & Percentage \\
\hline SSCE/GCE & 4 & 1.1 & Business & 60 \\
\hline OND & 30 & 8.6 & Business & 70 \\
\hline HND & 51 & 14.6 & Civil Servant & 45 \\
\hline NCE & 76 & 21.7 & Business & 40 \\
\hline B.A/B.Sc & 141 & 40.3 & Civil Servant & 65 \\
\hline M.A/M.Sc & 36 & 10.3 & Business & 35 \\
\hline Ph.D & 1 & 0.3 & Lecturer & 100 \\
\hline No Response & 11 & 3.1 & - & \\
\hline Total & 350 & 100.0 & & \\
\hline
\end{tabular}

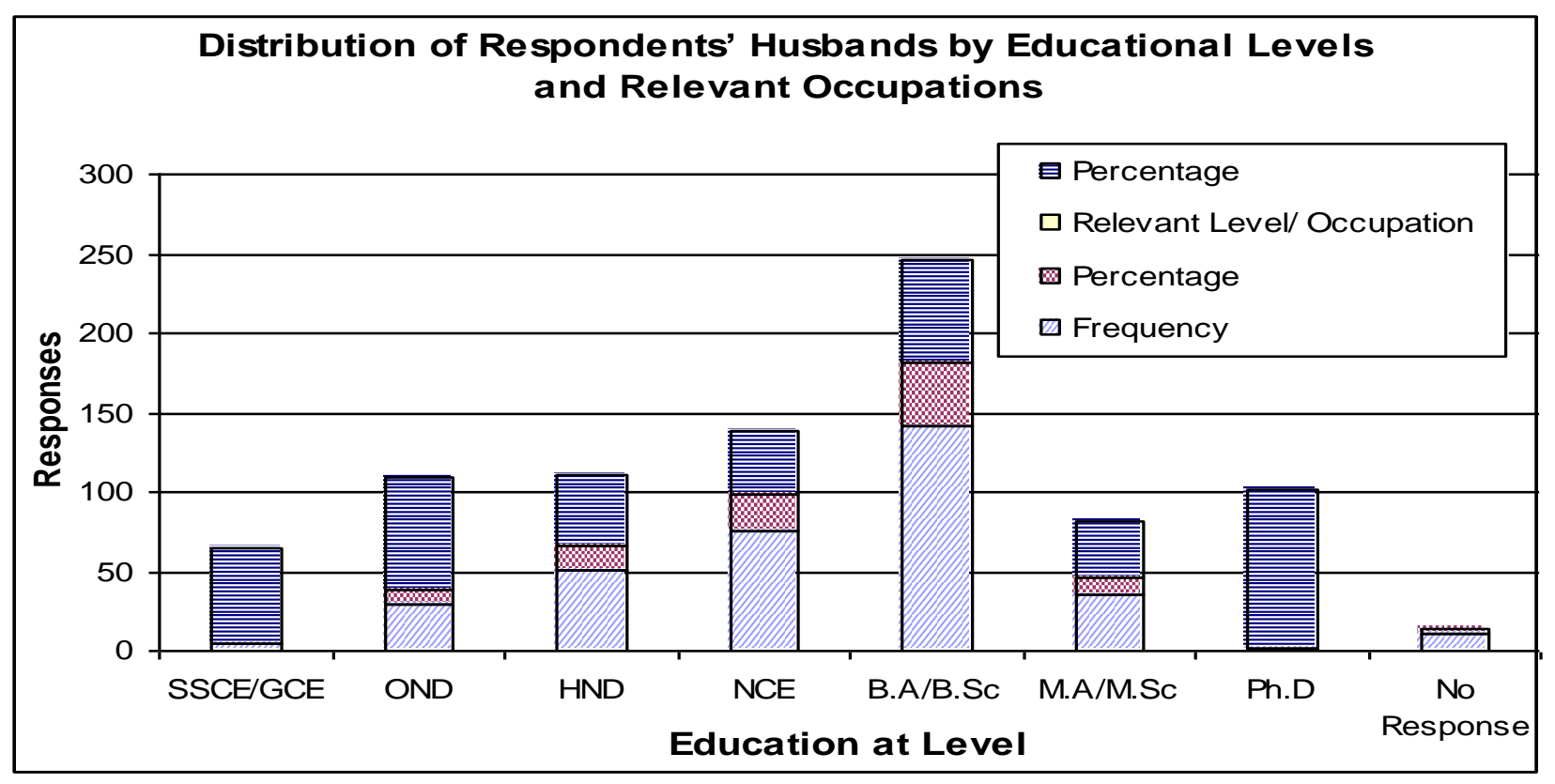

Table 10 shows that most of the respondents' husbands were educated through various levels. Forty point three percent of the husbands have a university first degree, while $10.3 \%$ have a Master's degree and $0.3 \%$ has a Ph.D. Twenty one point seven percent of the respondents' husbands have an NCE, $8.6 \%$ have OND and $14.6 \%$ are holders of HND.

The table also shows that $60 \%$ of respondents' husbands with school certificate, $70 \%$ of those with OND, $40 \%$ of NCE holders and 35\% who have Masters degrees are businessmen. Hence, the prevailing occupation for the husbands is business. $45 \%$ of HND graduates and $65 \%$ of husbands with university first degrees are civil servants. Only one (1) respondent's husband is in the academics.

\section{DISCUSSION}

The adult female literacy rate of less than $50 \%$ in Africa is the lowest in the world. In 1990, the adult literacy rate of males was $61 \%$ while that of females was $39 \%$ in the sub-Saharan Africa (Africa Platform for 
Action, 1994). Statistics show that in the Nigerian educational sector, the gross enrolment ratios for the girl-child are still very low, at 18 per cent, while the dropout rate stands at 47.8 per cent as at 1992 . There is also a clear trend of low enrolment of girls in the secondary and tertiary levels of education, most especially in Science, Technology and Mathematics (Africa Platform for Action, 1994). This high level of illiteracy among women is a serious impediment to national development as women make up more than $50 \%$ of the population.

The neglect of women's education has severely militated against rational national development. In spite of the spectacular expansion of educational facilities at all levels since independence, women have continued to be discriminated against for various socio-economic reasons (Umar, 2000).

The woman, assuming all the cultural and economic roles imposed on her by the society, wants and needs to be educated. However, a woman faces a major huddle in her quest for education: she has neither the time nor resources to attend school on a full-time basis. This is where Distance Education (DE) now comes in very handy. It comes to the rescue of the woman more than any one else. Afterall, distance education involves the application of the multimedia to supplement or reinforce the print media, thus making education more accessible to a much wider audience.

Education in its entire ramification has gone a long way in bringing about civilization. It is regarded as a dynamic instrument of change. Education has helped to pull individuals out of the pit of ignorance (Adekanola, 1998; Ekunbunor, 1997 and Umar, 2000). Distance Education bridges gender disparity in education (Isyaku, 2000) and empowers women in nation building (Adekanola, 1998; Fasusi, 1996; Nwukora, 1993; Oshodi, 1996 and Umar, 2000).

The many advantages of educating women especially through Distance Education, include the facts that:

- $\quad$ Educated women bear fewer children;

- $\quad$ Education of women is panacea to marternal and infant mortality;

- $\quad$ Educated women are more responsive to programmes of enlightenment, especially health programmes (Bamisaye, 2008; Osokoya, 2008);

- $\quad$ Educated women take more active role sin public life (politics) (Malcow, 2006);

- $\quad$ Educated women are more conscious of their rights and are able to fight for them;

- $\quad$ Education enhances better employment and promotion for women;

- $\quad$ Distance education empowers women.

\section{ABOUT THE AUTHORS}

A. O. Okunuga is a lecturer at the Distance Learning Institute, University of Lagos, Nigeria. He is the head of the Science-Education Program. He teaches Biology and Education courses.

M. O. Akintayo is a Professor of Economics of Education and Head of Department of the Adult Education Department, Faculty of Education, University of Ibadan, Nigeria.

\section{REFERENCES}

1. Adekanola, O. 1998. Women Empowerment And Nation Building, Punch (Newspaper), Friday, June 5, 1998, P.27.

2. Aderinoye, R.A. 2004. Adult And Non-Formal Education And The Global Challenges: Issues And Perspectives. $55^{\text {th }}$ Anniversary Lecture, Department Of Adult Education, University Of Ibadan.

3. Ativie, Cecilia O. 1997. Distance Education And Women Empowerment, B.Sc. Project, Distance Learning Institute, University Of Lagos, Akoka, Lagos.

4. Bamisaye, Ayodele, 2008. Gender Empowerment And Millennium Development Goals: Nigeria's Educational Perspective Education For Millennium Development, Essays In Honour Of Prof. Michael Omolewa (Ed) Marcie Boucouvalas And Rashid Aderinoye, Ibadan, Polygraphics Ventures Ltd., Vol.Ii, Pp. 36-51. 
5. $\quad$ Ekunbunor, Jemi. 1997. We Need A Policy On Aids. Sunday Vanguard, June 29, 1997, P.15.

6. $\quad$ Fasusi, Modupe. 1996. Women Will Soon Be Empowered. Sunday Champion, July 28, 1996.

7. Isyaku, K. 2000. Gender Disparity Worries Ncce Scribe. Vanguard, Tuesday, December 19, 2000 , P.3.

8. Malcom, S.M. 2006. Knowledge, Technology And Development Gendered Perspective. American Association For The Advancement Of Science

9. Obiona, Noela. 1993. Women Enrolment In Distance Education. A Paper Presented At The National Seminar On Distance Education At The Federal Polytechnic, Oko, Anambra State, Nigeria.

10. Obodeh, E. 1997. Distance Education And Women Empowerment. A B.Sc. (Educ.) Project Presented To The University Of Lagos.

11. Osokoya, I. Olu. 2008. Towards Maximising Women's Contribution To National Development Through Education In Nigeria. Education For Millennium Development Essays In Honour Of Prof. Michael Omolewa, Ibadan, Polygraphics Venture Ltd., Vol.Ii, Pp. 68-77.

12. Umar, Fatima. 2000. Distance Education May Replace Satellite Campuses. The Guardian, Thursday, October 26, 2000, Pp. 45-47.

13. Yinusa, Elizabeth O. 1999. Women Empowerment And Distance Education, B.Sc. (Educ.) Project, Unviersity Of Lagos, Akoka, Lagos. 
NOTES 